\title{
Modulation of the feeding response of lactating dairy cows to peripheral insulin administration with or without a glucose supply
}

\author{
N Bareille *, P Faverdin \\ Station de recherches sur la vache laitière, Inra, \\ 35590 Saint-Gilles, France
}

(Received 31 May 1995; accepted 14 December 1995)

\begin{abstract}
Summary - The aim of this study was to determine the effect of physiological amounts of insulin without glucoprivation on food intake of dairy cows. Four multiparous Holstein cows at 150 days postpartum were allocated to the treatments, consisting of a $4 \mathrm{~h}$ intravenous infusion of: 1) control (saline); 2) insulin (3.41 $\mu \mathrm{g} / \mathrm{kg})$; 3) glucose (2.75 mmol/ $\mathrm{kg}$ ); and 4) insulin plus glucose (same dosage). A complete diet was offered ad libitum and the intake behaviour was continuously recorded. The plasma insulin was only slightly increased during the insulin treatment, but the treatments including glucose increased it more. The insulin treatment increased dry matter intake during infusion $(+12 \% ; P<0.07)$, but the increase was offset during the following $4 \mathrm{~h}$. In contrast, dry matter intake was slightly decreased by insulin during the first hour of infusion $(-8 \% ; P<0.03)$ when the insulin-induced hypoglycemia was prevented by a concomitant infusion of glucose. The insulin-induced glucoprivation stimulated food intake, whereas glucose availability had no obvious satiating effect in dairy cows.
\end{abstract}

food intake / insulin / glucose / dairy cow

Résumé - Rôle du glucose et de l'insuline dans le contrôle de la prise et du comportement alimentaires de la vache laitière. L'objectif de cette étude était de déterminer si des modifications de disponibilité cellulaire en glucose par des doses physiologiques d'insuline pouvaient intervenir dans le contrôle de la prise alimentaire chez la vache laitière. Quatre vaches Prim'holstein multipares 150 jours post-partum ont été soumises à quatre traitements. Ils consistaient en une perfusion intraveineuse pendant 4 heures de : i) témoin (soluté salin), ii) insuline $(3,41 \mu \mathrm{g} / \mathrm{kg}$ ), iii) glucose $(2,75 \mathrm{mmol} / \mathrm{kg}$ ), et iv) insuline plus glucose $(3,41 \mu \mathrm{g} / \mathrm{kg}$ et $2,75 \mathrm{mmol} / \mathrm{kg}$ respectivement). Les animaux avaient en permanence accès à une ration complète et leur comportement alimentaire était enregistré. La perfusion d'insuline a accru linsulinémie, mais les traitements comportant une perfusion de glucose l'ont augmentée plus nettement. Le traitement insuline a augmenté les quantités de matières sèches ingérées pendant la perfusion $(+12 \%, p<0,07)$, cette augmentation étant compensée pendant les quatre heures suivantes. $\dot{A}$ l'opposé, la perfusion d'insuline a diminué les quantités ingérées pendant la première heure (-8 $\% ; \mathrm{p}<0,03$ ) lorsque l'hypoglycémie était empêchée par une perfusion concomitante de glucose. La glucopénie induite par linsuline stimule la prise alimentaire, mais une augmentation de la disponibilité en glucose n'a pas d'effet rassasiant évident chez la vache laitière.

prise alimentaire / insuline / glucose / vache laitière

* Present address: École nationale vétérinaire, CP 3013, 44087 Nantes cedex 3, France 


\section{INTRODUCTION}

The respective roles of insulin and glucose in the control of food intake in monogastric animals seem to be clearly established. Experiments carried out on monogastric animals and consisting of injecting a large amount of insulin (Mackay et al, 1940; Booth, 1972) or glucose antimetabolites (Houpt and Hance, 1971; Booth, 1972) have highlighted the role played by a decrease in the availability of cellular glucose in stimulating food intake. On the other hand, the glucose supply to cells by systemic glucose (Janowitz and Grossman, 1948) or insulin administration produces a satiating effect provided its hypoglycemic effects are compensated for (Nicolaïdis and Rowland, 1976; Woods et al, 1984; Even and Nicolaïdis, 1986).

Experiments carried out on ruminants to study the effect of glucose availability on the control of food intake are less frequently undertaken (Dulphy and Faverdin, 1987). The first glucose supply experiments performed on small ruminants did not lead to a modification in the food intake (Manning et al, 1959; Dowden and Jacobson, 1960; Holder, 1963). Acute injections of insulin without glucose supply in sheep (Deetz and Wangsness, 1980; Deetz and Wangsness, 1981) and dairy cows (Faverdin, 1986) resulted in a very temporary decrease in food intake during the hypoglycemia phase, often followed by a compensatory increase in food intake. However, if this satiating effect resulted from a higher glucose supply to the cells, the same phenomenon should have been observed with the glucose infusion alone. An insulin infusion of several hours without a concomitant glucose supply led to an increase in food intake in sheep (Anil and Forbes, 1980; Deetz et al, 1980). This increase could be explained by severe and prolonged glucopenia, as has been observed with rats. Prolonged insulin infusions on ruminants, however, had never been realized with concomitant glucose infusions given in order to avoid a decrease in glycemia. If the satiating effect of a single administration of insulin is due to increased cellular glucose availability, as is the case with rats, the result should be improved by a prolonged insulin and glucose infusion. in addition, a highyielding dairy cow, exporting large quantities of glucose via its mammary gland (Bickerstaffe et al, 1974) might be more sensitive to cellular glucose availability.

The aim of the experiment was to test for any implication of variations in glucose availability induced by physiological amounts of insulin on food intake control. The specific effects of insulin were dissociated from those caused by the concurrent drop in glycemia by simultaneously administering both glucose and insulin. The complete diet offered ad libitum to dairy cows was highly ingestible in order to avoid any physical limitation of food intake by the distension of the reticulo-rumen. All eating behaviour parameters including ruminating activities were taken into consideration when studying the results of these treatments.

\section{MATERIALS AND METHODS}

\section{Treatments and experimental design}

Four cows were assigned to treatments in an experimental design composed of three consecutive replications of a $4 \times 4$ Latin square with 2 day periods, without any readjustment interval in between. The treatments consisted of intrajugular infusion over a $4 \mathrm{~h}$ period of: 1) control (saline excipient); 2) insulin (3.41 $\mu \mathrm{g} / \mathrm{kg}$ body weight (BW)); 3) glucose (2.75 mmol $/ \mathrm{kg} \mathrm{BW})$; and 4) insulin plus glucose $(3.41 \mu \mathrm{g} / \mathrm{kg} \mathrm{BW}$ and 2.75 $\mathrm{mmol} / \mathrm{kg} \mathrm{BW}$, respectively). Insulin was first injected as a bolus $(0.26 \mu \mathrm{g} / \mathrm{kg} \mathrm{BW})$ and then by the $4 \mathrm{~h}$ infusion (13.1 $\mathrm{ng} / \mathrm{kg} \mathrm{BW} / \mathrm{min})$ whereas glucose was infused only. The treatments were administered by peristaltic pumps from 0800 to 1200 hours on alternate days. The effects of the treatments were monitored over 2 day periods. 
Porcine insulin (Endopancrine 10, Laboratoires Organon, France) was dissolved in $1.15 \mathrm{~L}$ of either $0.9 \% \mathrm{NaCl}$ or $30 \%$ glucose solution.

\section{Cows and diet}

The same four multiparous Holstein cows were used on the three replications. They averaged $700 \mathrm{~kg} \mathrm{BW}$ and $30.5 \mathrm{~kg} /$ day of milk on the week before the experiment. The treatments were initiated at $143 \pm 25$ (mean $\pm \mathrm{SE}$ ) days postpartum. The cows were housed in tiestalls in an artificially ventilated barn under a $24 \mathrm{~h}$ light regimen. A total mixed diet $(70 \%$ corn silage and $30 \%$ concentrate on a dry matter (DM) basis) was offered ad libitum (table I), in amounts designed to induce at least $15 \%$ of feed refusals. The animals had a permanent access to feed with two distributions per day at 0800 and 1800 hour, after milking.

\section{Measurements and sampling}

The amounts of feed offered and feed refusals were weighed daily and samples of the feed were analysed for their DM content, daily for the corn silage and weekly for the concentrate. The intake behaviour was monitored throughout the experiment by means of continuously weighed mangers. The chewing behaviour was recorded simultaneously by means of variations in pressure on a foam balloon placed submandibularly. All these data were recorded by microcompter (Baumont et al, 1990). The interpretation of the feeding activity was made minute by minute. A meal was considered as a sequence of chewing activity with manger weight variations at least 8 min apart from a subsequent meal. Rumination was defined as being a period of high chewing activity (at least 55 jaw movements per min for $10 \mathrm{~min}$ ) without any manger weight variations. By a process of elimination, the remainder was classified into resting sequence.

The milk yield was recorded at each milking. Milk samples were taken at all the milkings during the first replication, for measurements of the fat and protein contents. Only the evening milkings following treatment were analysed for a determination of the milk fatty acids.

A permanent catheter was inserted into both jugular veins at least one month before the beginning of the experiment. On the third replication, blood samples were withdrawn from the contralateral catheter at $0,0.5,1,2,3,4,5,6,7$ and $8 \mathrm{~h}$ relative to the beginning of infusion.

\section{Chemical analyses}

The milk was analysed for fat and protein content using infrared analysis (Milkoscan, Foss Electric, Hillerød, Denmark). The fatty acid composition of the cream was determined by gas chromatography as described previously (Bauchard and Duboisset, 1983).

Heparinized plasma was analysed for nonesterified fatty acids (NEFA) using an enzymatic

Table I. Ingredient and chemical composition of the average diet and its ingredients.

\begin{tabular}{|c|c|c|c|c|c|c|c|c|}
\hline Ingredient & $\begin{array}{l}\text { Percentage } \\
\text { of total diet }\end{array}$ & $\begin{array}{c}C P \text { a } \\
(\% \text { of } \\
D M)\end{array}$ & $\begin{array}{l}O M^{b} \\
(\% \text { of } \\
D M)^{\prime}\end{array}$ & $\begin{array}{c}\text { Cellulose } \\
\text { (\% of } \\
D M)\end{array}$ & $\begin{array}{l}A D F c \\
(\% \text { of } \\
D M)\end{array}$ & $\begin{array}{l}\text { NDF } d \\
(\% \text { of } \\
D M)\end{array}$ & $\begin{array}{c}\text { Energy } \\
(M c a l / k g \\
\text { of DM })\end{array}$ & $\begin{array}{c}P D / \text { e } \\
(g / k g \text { of } \\
D M)\end{array}$ \\
\hline Corn silage & 70.0 & 7.7 & 95.7 & 22.7 & 26.7 & 46.3 & 1.57 & 75 \\
\hline Concentrate $^{f}$ & 30.0 & 35.8 & 94.6 & 4.3 & 4.8 & 13.8 & 1.96 & 169 \\
\hline Total diet $\mathrm{g}$ & 100.0 & 16.1 & 95.4 & 17.2 & 20.1 & 36.5 & 1.69 & 103 \\
\hline
\end{tabular}

a Crude protein; ${ }^{b}$ organic matter; ${ }^{c}$ acid detergent fibre; ${ }^{d}$ neutral detergent fibre; ${ }^{e}$ protein digested in the small intestine (ie, similar to absorbable protein); ${ }^{\dagger}$ contains $28.1 \%$ formaldehyde treated soybean meal, $20.3 \%$ soybean meal, $17.5 \%$ corn, $17 \%$ wheat, $11.5 \%$ barley, $1.6 \%$ urea, $1.5 \%$ molasses, $0.5 \%$ fat, $2 \%$ mineral salts; $g$ twice daily $0.15 \mathrm{~kg}$ of a mineral premix. 
kit (acyl-coenzyme A synthetase, acyl-coenzyme A oxidase method; Wako Chemicals Gmbh, Neuss, Germany). Deproteinized plasma ( $1 \mathrm{~mL}$ of plasma and $2 \mathrm{~mL}$ of $\mathrm{HClO}_{4}$ by filtration) was analysed for glucose (Trinder, 1969) with an Isamat ${ }^{\circledR}$ autoanalyzer (ISA Biologie, Cachan, France) and for urea by a colorimetric diacetylmonoxime procedure with a continuous flux analyser (Technicon Industrial Systems, New York, NY) (Moore and Sax, 1965).

Plasma from the ethylenediamine-tetracetic acid (EDTA) syringes was used for the insulin radioimmunoassay (Rosselin et al, 1966, modified by Faverdin, 1985). The labelled insulin was porcine insulin iodinated with I125 (ISI, Saclay, France). A guinea-pig anti-bovine insulin serum (Miles Laboratories Ltd, Slough, UK) was used as the antibody. A bovine monocomponent insulin (Novo, Copenhagen, Denmark) was used as a standard. Separation of the free and antibodybound insulin was performed by adsorption of the free labelled insulin on charcoal. With this assay, cross-reactions between bovine insulin and bovine proinsulin (Novo, Copenhagen, Denmark) are close to $40 \%$, but are very weak between bovine insulin and glucagon (Sigma Chimie, SaintQuentin-Fallavier, France).

\section{Statistical analyses}

The data sets were all analysed using the general linear model procedure of the SAS (1987). The statistical model for the analysis was:

$$
Y_{i j k l}=\mu+t_{i}+r_{j}+p_{k}\left(r_{j}\right)+c_{l}\left(r_{j}\right)+e_{i j k l}
$$

where: $\mu$ is the overall mean; $t_{j}$ is the effect of treatment $i, r_{j}$ is the effect of replication $j ; p_{k}\left(r_{j}\right)$ is the effect of period $k$ within replication $\mathrm{j} ; c_{i}\left(r_{j}\right)$ is the effect of cow / within replication $j$; and $e_{i j k j}$ is the residual error term.

Before any analysis of variance ( $F$ test), the non-heterogeneity of variance between treatments was tested with a Hartley test. The effects of treatments were tested with the three following pre-planned orthogonal contrasts with $e_{i j k l}$ as common residual error term: contrast $A$ : effect of insulin alone treatment (insulin vs control); contrast $B$ : effect of insulin plus glucose treatment (insulin plus glucose vs glucose); and contrast C: mean effect of glucose treatment ([insulin plus glucose and glucose] vs [insulin and control]).
A log transformation was used for the plasma insulin analysis. For the analysis of the kinetics of intake, three phases were distinguished in order to observe the early effects of infusions (during the first hour), their late effects (during the last $3 \mathrm{~h}$ ) and their delayed effects (during the following $4 \mathrm{~h}$ ).

Only values of $P<0.10$ are displayed in the tables.

\section{RESULTS}

\section{Food intake}

During infusion, dry matter intake (DMI) and eating time were increased with insulin-alone treatment (table II). This increase occurred during the last $3 \mathrm{~h}$ of infusion ( $P=0.07$; fig 1 ) and was largely due to an increase in eating time $(P<0.10)$. The insulin plus glucose treatment produced a satiating effect compared to the glucose treatment during the first hour $(P=0.03)$. The treatments including a glucose infusion did not affect food intake, but increased the ruminating time to a small extent during the $4 \mathrm{~h}$ of perfusion $(+11 \mathrm{~min}$; $P$ $<0.06$ ). The other components of feeding behaviour were not modified by the treatments (table II). In particular, no relationship was found between the first meal size and the duration of the post-meal interval.

A significant decrease of food intake was observed during the $4 \mathrm{~h}$ following the infusion of insulin-alone treatment $(P=0.07$; fig 1). Over the whole day, neither the eating (total DMI, eating time and eating rate) nor ruminating parameters were significantly altered by the treatments (table II). The overeating effects of insulin were offset when the day as a whole was considered.

\section{Milk yield and composition}

The milk yield was slightly decreased by the insulin-alone treatment $(-1.3 \mathrm{~kg} /$ day; $P<$ 
Table II. Effects of treatment on food intake and feeding behaviour on the day of treatment.

\begin{tabular}{|c|c|c|c|c|c|c|c|c|}
\hline & \multirow[t]{2}{*}{ Control } & \multirow[t]{2}{*}{ Insulin } & \multirow[t]{2}{*}{ Glucose } & \multirow{2}{*}{$\begin{array}{l}\text { Insulin + } \\
\text { glucose }\end{array}$} & \multirow[t]{2}{*}{$S E$ a } & \multicolumn{3}{|c|}{ Contrast $\mathrm{b}$} \\
\hline & & & & & & $A$ & $B$ & $c$ \\
\hline \multicolumn{9}{|l|}{ During infusion } \\
\hline Dry matter intake $(\mathrm{kg})$ & 7.3 & 8.2 & 7.9 & 7.5 & 0.37 & 0.10 & NS & NS \\
\hline Number of meals & 2.2 & 2.5 & 2.8 & 2.3 & 0.27 & NS & NS & NS \\
\hline Eating time (min) & 100 & 111 & 108 & 101 & 4.4 & 0.10 & NS & NS \\
\hline Ruminating time (min) & 54 & 50 & 58 & 67 & 5.5 & NS & NS & 0.06 \\
\hline First meal size $(\mathrm{kg})$ & 5.2 & 5.5 & 5.5 & 5.2 & 0.27 & NS & NS & NS \\
\hline Post-meal interval time (min) & 80 & 75 & 75 & 91 & 18.5 & NS & NS & NS \\
\hline \multicolumn{9}{|l|}{ The whole day } \\
\hline Dry matter intake (kg/day) & 22.8 & 22.6 & 22.5 & 22.0 & 0.34 & NS & NS & NS \\
\hline Number of meals & 10.8 & 10.8 & 10.9 & 11.3 & 0.45 & NS & NS & NS \\
\hline Eating time (min) & 332 & 333 & 328 & 330 & 5.1 & NS & NS & NS \\
\hline Eating rate $(\mathrm{g} \mathrm{DM} / \mathrm{min})$ & 69.2 & 68.3 & 69.3 & 67.3 & 1.03 & NS & NS & NS \\
\hline Ruminating time ${ }^{c}(\min /$ day $)$ & 547 & 535 & 548 & 531 & 12.0 & NS & NS & NS \\
\hline
\end{tabular}

a $n=12$; ${ }^{b}$ contrast A: insulin vs control; contrast $B$ : insulin + glucose vs glucose; contrast $C$ : (insulin + glucose and glucose) vs (control and insulin); NS: $P>0.10$; elsewhere: $P$ value; ${ }^{c}$ three data were withdrawn.

0.08) (table III). The treatments including glucose increased the milk yield $(+1.1 \mathrm{~kg} /$ day; $P<0.04)$ and decreased the milk fat $(-2.0 \mathrm{~g} / \mathrm{kg} ; P<0.05)$ and protein contents $(-0.9 \mathrm{~g} / \mathrm{kg} ; P<0.02)$. The fat and protein yields were not modified by treatments (table III). The milk fatty acid composition was slightly modified (table IV): the treatments including insulin increased slightly but significantly the proportion of odd-numbered fatty acids either with or without a glucose supply.

The energy balance was not significantly modified by the different treatments (table III) and remained positive over the experiment.
Fig 1. Effect of treatments on the cumulated food intake during and after intravenous infusion. The infusion occurred from 0800 to 1200 hours. Control (saline excipient) is shown by open bars, insulin (3.41 $\mu \mathrm{g} / \mathrm{kg} \mathrm{BW}$ ) by grey bars, glucose $(2.75 \mathrm{mmol} / \mathrm{kg} \mathrm{BW})$ by hatched bars and insulin plus glucose (same dosage) by black bars. $A$ and $B$ are shown when the contrast $A$ (insulin vs control) or $B$ (insulin plus glucose vs glucose) are significant ( $P$ $<0.10)$. Means \pm SE $(n=12)$.

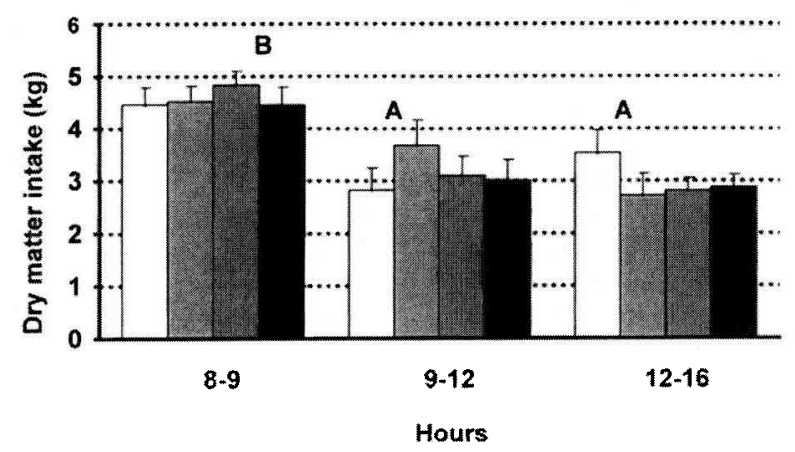


Table III. Effect of treatments on nutrient balance, milk yield and composition on the day of treatment.

Control Insulin Glucose Insulin + SE

$\frac{\text { Contrast }^{b}}{\text { A }}$ B $\quad$ C

\begin{tabular}{|c|c|c|c|c|c|c|c|c|}
\hline \multicolumn{9}{|l|}{ Diet } \\
\hline Energy intake a (Mcal of NEI) & 36.3 & 36.0 & 35.9 & 35.0 & 0.54 & NS & NS & NS \\
\hline Energy balance c,d (Mcal of NEI) & l) 4.9 & 4.4 & 4.6 & 4.4 & 1.02 & NS & NS & NS \\
\hline \multicolumn{9}{|l|}{ Vields $\mathrm{e}$} \\
\hline Milk a (kg/day) & 28.6 & 27.3 & 29.0 & 29.1 & 0.51 & 0.08 & NS & 0.04 \\
\hline $4 \%$ FCM $^{\mathrm{c}}(\mathrm{kg} /$ day $)$ & 30.7 & 30.9 & 29.9 & 30.7 & 0.91 & NS & NS & NS \\
\hline Fat ${ }^{\circ} \mathrm{g} / \mathrm{d}$ & 1228 & 1235 & 1196 & 1227 & 21.0 & NS & NS & NS \\
\hline Protein $^{c} \mathrm{~g} / \mathrm{d}$ & 940 & 932 & 929 & 951 & 6.9 & NS & NS & NS \\
\hline \multicolumn{9}{|l|}{ Milk composition e } \\
\hline Fat ${ }^{\circ}(\%)$ & 4.20 & 4.29 & 4.00 & 4.09 & 0.08 & NS & NS & 0.05 \\
\hline True protein $\mathrm{c}(\%)$ & 3.21 & 3.23 & 3.11 & 3.16 & 0.02 & NS & NS & 0.02 \\
\hline
\end{tabular}

a $n=12 ;{ }^{b}$ contrast A: insulin vs control; contrast B: insulin + glucose vs glucose; contrast $C$ : (insulin + glucose and glucose) vs (control and insulin); NS: $P>0.10$; elsewhere: $P$ value; ${ }^{c}$ data on the first Latin square; $n=4 ;^{d}$ difference between energy intake and energy requirement for maintenance of milk yield; e sum of the two milkings following treatment.

Table IV. Effect of treatments on milk fatty acid composition.

\begin{tabular}{|c|c|c|c|c|c|c|c|c|}
\hline \multirow{2}{*}{$\begin{array}{l}\text { Fatty acids } \\
(\%)\end{array}$} & \multirow[t]{2}{*}{ Control } & \multirow[t]{2}{*}{ Insulin } & \multirow[t]{2}{*}{ Glucose } & \multirow{2}{*}{$\begin{array}{l}\text { Insulin + } \\
\text { glucose }\end{array}$} & \multirow[t]{2}{*}{$S E^{\mathrm{a}}$} & \multicolumn{3}{|c|}{ Contrast $b$} \\
\hline & & & & & & $A$ & $B$ & $C$ \\
\hline $\begin{array}{l}C_{4}-C_{12} c \\
C_{14} d \\
C_{15}+C_{17} d \\
C_{16} d \\
C_{18}^{d}\end{array}$ & $\begin{array}{r}14.24 \\
14.24 \\
3.75 \\
40.74 \\
27.03\end{array}$ & $\begin{array}{r}13.57 \\
13.44 \\
3.90 \\
42.31 \\
26.78\end{array}$ & $\begin{array}{r}14.60 \\
14.83 \\
3.57 \\
40.12 \\
26.88\end{array}$ & $\begin{array}{r}13.66 \\
13.89 \\
3.97 \\
41.61 \\
26.87\end{array}$ & $\begin{array}{l}0.34 \\
0.49 \\
0.04 \\
0.95 \\
0.27\end{array}$ & $\begin{array}{l}\text { NS } \\
\text { NS } \\
0.03 \\
\text { NS } \\
\text { NS }\end{array}$ & $\begin{array}{c}0.10 \\
\text { NS } \\
0.01 \\
\text { NS } \\
\text { NS }\end{array}$ & $\begin{array}{l}\text { NS } \\
\text { NS } \\
\text { NS } \\
\text { NS } \\
\text { NS }\end{array}$ \\
\hline
\end{tabular}

a $n=4$; ${ }^{b}$ contrast $A$ : insulin vs control; contrast $B$ : insulin + glucose vs glucose; contrast $C$ (insulin + glucose and glucose) vs (control and insulin); NS; $P>0.10$; elsewhere; $P$ value; ${ }^{c}$ sum of short chain fatty acids; ${ }^{d}$ sum of $C_{x}$ fatty acids.

\section{Blood parameters}

Under the insulin treatment, the insulin concentrations were significantly increased (+60\%; $P<0.04)$, but the glucose treatment, alone or associated with insulin, increased the insulinemia to a larger extent $(+350$ and
$+310 \%$ respectively; $P<0.01$ ) (table $\mathrm{V}$; fig 2). The insulin concentrations under these two treatments did not differ significantly. However, the insulin and the insulin plus glucose treatments significantly $(P<$ 0.01 ) decreased the glycemia compared to the control and glucose treatments, respec- 
Table V. Effect of treatments on blood parameters.

Control Insulin Glucose $\begin{aligned} & \text { Insulin }+ \\ & \text { glucose }\end{aligned}$ SE a

$\frac{\text { Contrast }^{b}}{\text { A }}$ B C

During infusion c

$\begin{array}{lcccccccc}\text { Insulin }(\mathrm{ng} / \mathrm{mL}) & 1.12 & 1.79 & 3.88 & 3.48 & 0.32 & 0.04 & \text { NS } & 0.01 \\ \text { Glucose }(\mathrm{mmol} / \mathrm{L}) & 3.5 & 2.8 & 4.8 & 4.1 & 0.08 & 0.01 & 0.01 & 0.01 \\ \text { NEFA }(\mu \mathrm{mol} / \mathrm{L}) & 25.7 & 24.2 & 22.3 & 20.2 & 1.91 & \text { NS } & \text { NS } & 0.10 \\ \text { Urea }(\mathrm{mmol} / \mathrm{L}) & 6.25 & 6.17 & 6.05 & 6.47 & 0.20 & \text { NS } & \text { NS } & \text { NS }\end{array}$

\section{After infusion ${ }^{\mathrm{c}}$}

$\begin{array}{lcccccccc}\text { Insulin }(\mathrm{ng} / \mathrm{mL}) & 1.09 & 1.20 & 1.10 & 1.16 & 0.08 & \text { NS } & \text { NS } & \text { NS } \\ \text { Glucose }(\mathrm{mmol} / \mathrm{L}) & 3.5 & 3.5 & 3.4 & 3.6 & 0.08 & \text { NS } & \text { NS } & \text { NS } \\ \text { NEFA }(\mu \mathrm{mol} / \mathrm{L}) & 15.7 & 19.9 & 18.8 & 15.9 & 2.09 & \text { NS } & \text { NS } & \text { NS } \\ \text { Urea }(\mathrm{mmol} / \mathrm{L}) & 5.73 & 5.82 & 5.33 & 6.00 & 0.21 & \text { NS } & 0.07 & \text { NS }\end{array}$

a $n=4$; b contrast A: insulin vs control; contrast B: insulin + glucose vs glucose; contrast C: (insulin + glucose and glucose) vs (control and insulin); NS: $P>0.10$; elsewhere: $P$ value; ${ }^{c}$ means of four hourly samples.

tively (table V; fig 3). One hour after the end of the infusion, all these effects ceased (fig 2). The glycemia dropped during the insulin- alone treatment to $2.6 \mathrm{mmol} / \mathrm{L}$ after $3 \mathrm{~h}$ (fig 3). The amount of glucose infused with insulin neutralized the insulin-induced hypoglycemia, and even caused a slight hyperglycemia ( 4.1 vs $3.5 \mathrm{mmol} / \mathrm{L}$ for control treatment) (table $V$ ). One hour after the end of the infusions, the initial levels of glucose and insulin were recovered.

The treatments did not significantly affect the NEFA which remained at a very low level under all the treatments (table V). After
Fig 2. Effect of treatments on insulin concentrations during and after intravenous infusion. Control (saline excipient) is shown by verticle lines showing pooled SE, insulin $(3.41 \mu \mathrm{g} / \mathrm{kg} \mathrm{BW})$ by squares, glucose $(2.75 \mathrm{mmol} / \mathrm{kg}$ BW) by triangles and insulin plus glucose (same dosage) by circles. Treatments were administered intravenously from 0800 to 1200 hours. $A$ and $C$ are shown when the contrasts $A$ (insulin vs control) or $\mathrm{C}$ ([insulin + glucose and glucose] vs [insulin and control]) are significant $(P<0.10$ and $P<0.01$, respectively). Means $\pm \mathrm{SE}(n=4)$.

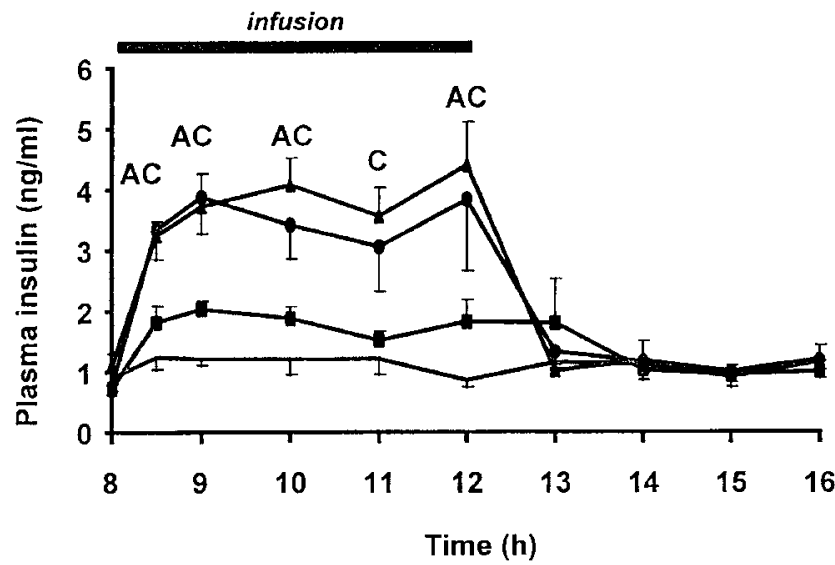




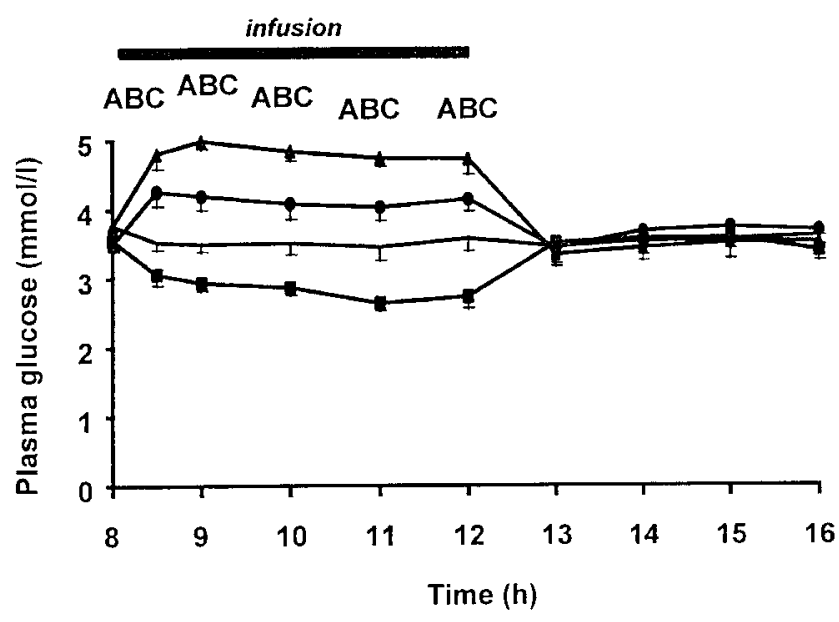

Fig 3. Effect of treatments on glucose concentrations. Control (saline excipient) is shown by verticle lines showing pooled SE, insulin $(3.41 \mu \mathrm{g} / \mathrm{kg}$ $\mathrm{BW})$ by squares, glucose ( 2.75 $\mathrm{mmol} / \mathrm{kg} \mathrm{BW}$ ) by triangles and insulin plus glucose (same dosage) by circles. Treatments were administered intravenously from 0800 to 1200 hours. $A, B$ and $C$ are shown when the contrast $A$ (insulin vs control), B (insulin + glucose vs glucose) or $\mathrm{C}$ ([insulin + glucose and glucose] vs [insulin and control]) are significant $(P<0.01)$. Means \pm SE $(n=4)$. the infusion, there was a trend $(P<0.07)$ towards a decrease in the urea concentrations with the glucose-alone treatment (table V).

\section{DISCUSSION}

The amounts of insulin were kept at moderate levels in this experiment in order to evaluate the real roles of insulin under physiological conditions. Literature reviews of the effect of insulin on food intake showed that a dose of $3.41 \mu \mathrm{g} / \mathrm{kg}$ was expected to produce a satiety effect (10-20\% reduction of DMI) (Dulphy and Faverdin, 1987; Grovum, 1995). Insulinemia was doubled during the insulin infusion but remained at physiological levels, and the hypoglycemia observed was moderate compared to most of the previous trials (Baile and Mayer, 1968; Houpt, 1974; Nicholson, 1979; Hikosaka et al, 1979; Deetz and Wangsness, 1980; Deetz et al, 1980). The amount of glucose infused was determined on the basis of the preliminary trials, in order to restore normoglycemia. The cows were in a less advanced lactating stage during these preliminary trials, which could have induced a higher glucose metabolic clearance rate (Denbow et al, 1986). This could explain why during the experiment, a slight hyperglycemia occurred when infusing glucose plus insulin. This intravenous supply of $340 \mathrm{~g}$ of glucose on average over $4 \mathrm{~h}$ is a large flow for a dairy cow (equivalent to a daily flow of $2 \mathrm{~kg}$ of glucose), especially when we consider that with normal mixed diets several studies found no net glucose absorption from the portal drained viscera (Nocek and Tamminga, 1991).

The infusion of glucose by itself induced a strong increase in insulinemia compared with the infusion of exogenous insulin. This result has already been observed in sheep (Hikosaka et al, 1979), where in order to obtain an insulinic response comparable to that of a glucose infusion, large amounts of insulin had to be infused. The concomitant intravenous supply of glucose and insulin did not have any additive effect on insulinemia. Exogenous insulin was recognized as endogenous insulin in the radioimmunoassay of insulin (Faverdin, 1985). The absence of a difference in insulinemia observed with glucose and insulin plus glucose treatments could be due to a difference in clearance rate of the endogenous 
and the exogenous insulin. Nevertheless, the lower glycemia observed with the insulin plus glucose treatment compared with the glucose alone confirms a higher activity of the exogenous insulin.

The milk yield was increased with the treatments including glucose, and the fat and protein contents were decreased by a dilution effect. In contrast, insulin decreased the milk yield. These changes resulted from an increase or a decrease of the plasma glucose availability (Kronfeld et al, 1963). The treatments including insulin increased the proportion of the odd-numbered fatty acids, probably because of a negative effect of insulin on the hepatic gluconeogenesis and the hepatic utilization of propionate (McDowell, 1983). However, the minor changes in milk yield and composition did not modify energy requirements and could not interfere with food intake. Whatever the treatment, the lipid metabolism of cows was mainly lipogenetic, as shown by the positive energy balances and very low plasma NEFA levels revealing very limited lipolytic activity.

This experiment was designed to study the possible satiating effect of insulin without glucopenia using a hyperinsulinemic/euglycemic pseudo-clamp. The higher glucose uptake obtained (as supported by the glycemia level) induced an early decrease of food intake during the first hour of the infusion compared with the glucose alone treatment. With a sustained hyperinsulinemic-euglycemic clamp, MacGuire et al (1995) observed a significant decrease in food intake only after 4 days, perhaps as a result of subsequent metabolic disorders. These data, obtained with a higher amount of insulin than in our trials (plasma insulin levels of 9 vs $3.5 \mathrm{ng} / \mathrm{mL}$ on average during infusion), suggested that a concomitant intravenous supply of glucose and insulin had no or transient satiating effect in the lactating dairy cow. In contrast, in the normal rat, an obvious satiating effect was obtained: a $4 \mathrm{~h}$ infusion of glucose, alone or with a concomitant infusion of insulin $(74 \mu \mathrm{g} / \mathrm{kg})$, significantly reduced food intake by 40 and $70 \%$, respectively (Even and Nicolaïdis, 1986). It seems that this effect is mainly a ruminant feature rather than a consequence of the lactation. In early lactating dairy goats, an impaired insulin-stimulated glucose utilization by the extramammary tissues was demonstrated, but during the mid-lactation and the dry period no more disruption in glucose utilization was shown (Debras et al, 1989). Moreover, in our experiment with mid-lactating dairy cows, a glucose supplement given during the preferential period of food intake did not modify the food intake parameters. Our results agree with previous data obtained in non-lactating ruminants (Manning et al, 1959; Dowden and Jacobson, 1960; Holder, 1963).

The slight effect of an increase of cellular glucose availability on food intake in ruminants was also observed in obese Zucker rats. An insulin plus glucose infusion during a $4 \mathrm{~h}$ period only slightly decreased food intake whereas normal rats displayed a total satiating effect ( 48 vs $95 \%$ decrease of food intake) (Orosco et al, 1994). It was considered to be consecutive to the insulin resistance of the Zucker rat. No obvious peripheral insulin resistance exists in the mid-lactating dairy cow (Debras et al, 1989). The transient effect of glucose availability could rather be explained by the endogenous origin of this nutrient. The feed ration used in this experiment provided a small glucose flow in the small intestine. Glucose, therefore, was mainly provided for the organism by hepatic glyconeogenesis (Casse et al, 1994).

Under our experimental conditions, the insulin-alone treatment induced a moderate hypoglycemia sustained for $4 \mathrm{~h}$. A significant increase in food intake occurred during infusion $(+12 \%$ DMI) but not over the whole day. This increase only occurred after $1 \mathrm{~h}$ of infusion when the availability of glu- 
cose was decreased. In sheep, a higher glucopenia maintained for several hours was needed to observe a stronger stimulant effect on food intake (Anil and Forbes, 1980; Deetz et al, 1980). Nevertheless, with hay rations, ie, rations with a lower digestibility (Hikosaka et al, 1979), or with more physiological amounts of insulin, the stimulatory effect on appetite did not occur (Anil and Forbes, 1980; Deetz et al, 1980). Many experiments have studied the changes in food intake induced by a single administration of insulin. A literature review showed that the effect varied according to the amount administered (Dulphy and Faverdin, 1987). In large amounts, insulin quickly induced hypoglycemia and cellular glucoprivation (Baile and Mayer, 1968; Houpt, 1974; Deetz et al, 1980). It could either lead to an increase of food intake (Houpt, 1974; Deetz et al, 1980) or had no effect (Baile and Mayer, 1968; Baile and Martin, 1970; Muller and Colenbrander, 1970; Deetz and Wangsness, 1980). In physiological amounts, which caused a slight hypoglycemia, acute insulin injection showed a short-term satiating effect that could be due to a large increase in the transport and the use of glucose into the cells (Deetz and Wangsness, 1980; Deetz et al, 1980; Deetz and Wangsness, 1981; Faverdin, 1986). In this trial, the transient decrease in DMI induced by insulin when glucose was also infused was perhaps due to the combination of the initial injection of insulin when glucose was highly available. Nevertheless, this effect was not always obtained (Deetz and Wangsness, 1980; Deetz et al, 1980; Faverdin, 1986) when the amounts of insulin alone or the nutritional status of the animals differed. In this trial, the satiating effect of insulin treatment could not be observed, perhaps because the glucose availability was the limiting factor.

A study carried out in sheep revealed a decrease in the rumination time during treatments involving high insulin doses (Nichol- son, 1979). These effects were not observed under our experimental conditions, where the hypoglycemia was more moderate. Impaired rumination may be due to a decrease in gastric motility caused by severe hypoglycemia.

In lactating dairy cows, the insulininduced glucoprivation stimulated food intake. There was no main effect of insulin infusion when a simultaneous glucose supply prevented hypoglycemia, except a transient reduction of food intake at the beginning of the infusion. On average, glucose infusion did not modify food intake.

\section{ACKNOWLEDGMENTS}

The authors are grateful to $\mathrm{H}$ Hétault, $\mathrm{P}$ Lamberton and all the crew for the cow welfare and feeding; and $M$ Texier, $M$ Vérité, $M$ Ermel and $L$ Toullec for their technical assistance.

\section{REFERENCES}

Anil MH, Forbes JM (1980) Effects of insulin and gastrointestinal hormones on feeding and plasma insulin levels in sheep. Horm Metab Res 12, 234-236

Baile CA, Mayer J (1968) Effects of insulin-induced hypoglycemia and hypoacetoemia on eating behavior in goats. J Dairy Sci 51, 1495-1499

Baile CA, Martin FH (1970) Hormones and amino acids as possible factors in the control of hunger and satiety in sheep. J Dairy Sci 54, 897-905

Bauchart D, Duboisset $F$ (1983) Utilisation des colonnes capillaires de verre pour l'analyse des acides gras du lait. Cahiers Techniques de l'Institut National de Recherche Agronomique. Bull Liaison Interne 1, 5354

Baumont R, Seguier N, Dulphy JP (1990) Rumen fill, forage palatability and alimentary behaviour in sheep. J Agric Sci Camb 115, 277-284

Bickerstaffe R, Annison EF, Linzell JL (1974) The metabolism of glucose, acetate, lipids and amino acids in lactating dairy cows. J Agric Sci Camb 82, 71-85

Booth DA (1972) Modulation of the feeding response to peripheral insulin, 2-deoxyglucose or 3-0-methyl glucose injection. Physiol Behav 8, 1069-1076

Casse EA, Rulquin H, Huntington GB (1994) Effect of mesenteric vein infusion of propionate on splanchnic 
metabolism in primiparous Holstein cows. $J$ Dainy Sci 77, 3296-3303

Debras E, Grizard J, Aina E, Tesseraud S, Champredon C, Arnal M (1989) insulin sensitivity and responsiveness during lactation and dry period in goats. Am J Physiol 256, E295-E302

Deetz LE, Wangsness PJ (1980) Effect of intrajugular administration of insulin on feed intake, plasma glucose and plasma insulin of sheep. $J$ Nutr 110, 1976-1982

Deetz LE, Wangsness PJ (1981) Effect of intrajugular administration of insulin, glucagon and propionate on voluntary feed intake of sheep. J Anim Sci 53 , 427-433

Deetz LE, Wangsness PJ, Kavanaugh JF, Griel LC (1980) Effect of portal and continuous intrajugular administration of insulin on feeding in sheep. J Nutr 110, 1983-1991

Denbow CJ, Perera KS, Gwazdauskas FC, Akers RM, Pearson RE, McGilliard ML (1986) Effect of season and stage of lactating on plasma insulin and glucose following glucose injection in holstein cattle. J Dairy Sci $69,211-216$

Dowden DR, Jacobson DR (1960) Inhibition of appetite in dairy cattle by certain intermediate metabolites. Nature (Lond) 188, 148-149

Dulphy JP, Faverdin P (1987) L'ingestion alimentaire chez les ruminants : modalités et phénomènes associés. Reprod Nutr Develop 27, 129-155

Even P, Nicolaïdis S (1986) Short-term control of feeding: limitation of the glucostatic theory. Brain Res Bull 17, 621-626

Faverdin $\mathrm{P}$ (1985) Régulation de l'ingestion des vaches laitières en début de lactation : étude du rôle de l'insuline. Thèse docteur ingénieur, INA-PG, $131 \mathrm{p}$

Faverdin P (1986) Injections de doses physiologiques d'insuline chez la vache en lactation : effets sur les quantités ingérées et les métabolites sanguins. Reprod Nutr Develop 26, 383-384

Grovum WL (1995) Mechanism explaining the effects of short chain fatty acids on feed intake in ruminants - osmotic pressure, insulin and glucagon. In: Ruminant Physiology: Digestion, Metabolism, Growth and Reproduction. Proceedings of the Eighth International Symposium on Ruminant Physiology (W Engelhardt, S Leonhard-Marek, G Breves, D Giesecke, eds), Ferdinand Enke Verlag, Stuttgart, 173-197

Hikosaka K, Sasaki Y, Tsuda T (1979) Effects of glucose, insulin and FFA in food intake in the sheep. Ann Rech Vét 10, 237-239

Holder JM (1963) Chemostatic regulation of appetite in sheep. Nature (Lond) 200, 1074-1075

Houpt TR (1974) Stimulation of food intake in ruminants by 2-deoxy-D-glucose and insulin. Am J Physio/ 227, 161-167
Houpt TR, Hance TE (1971) Stimulation of food intake in the rabbit and the rat by inhibition of glucose metabolism with 2-deoxy-D-glucose. J Comp Physiol Psychol 76, 395-400

Janowitz H, Grossman MI (1948) Effect of parenteral administration of glucose and protein hydrolysate on food intake in the rat. Am J Physiol 155, 28-32

Kronfeld DS, Mayer GP, Robertson JM, Raggi F (1963) Depression of milk secretion during insulin administration. J Dairy Sci 46, 553-561

MacGuire MA, Griinari JM, Dwyer DA, Bauman DE (1995) Role of insulin in the regulation of mammary synthesis of fat and protein. J Dairy Sci $78,816-$ 824

MacKay EM, Calloway JW, Barnes RH (1940) Hyperalimentation in normal animals produced by protamine zinc insulin. J Nutr 20, 59-66

Manning R, Alexander GI, Krueger HM, Bogart R (1959) The effect of intravenous glucose injections on appetite in adult ewes. Am J Vet Res 20, 242-246

McDowell GH (1983) Hormonal control of glucose homoeostasis in ruminants. Proc Nutr Soc 42, 149167

Moore JJ, Sax SM (1965) A revised automated procedure for urea nitrogen. Clin Chim Acta 11, 475-476

Muller LD, Colenbrander VF (1970) Effect of insulin administration on blood acetate and feed intake of sheep. J Anim Sci 31, 145-148

Nicolaïdis S, Rowland N (1976) Metering of intravenous versus oral nutrients and regulation of energy balance. Am J Physiol 231, 661-668

Nicholson T (1979) Some effects of insulin on eating and rumination. Ann Rech Vét 10, 231-233

Nocek JE, Tamminga S (1991) Site of digestion of starch in the gastrointestinal tract of dairy cows and its effect on milk yield and composition. J Dairy Sci 74 , 3598-3629

Orosco M, Rouch C, Nicolaidis S (1994) Resistance of the obese zucker rat to insulin-induced feeding and to satiety induced by coinfusion of insulin and glucose. Appetite 23, 209-218

Rosselin G, Assan R, Yalow RS, Berson SA (1966) Separation of antibody-bound and unbound peptide hormones labelled with iodine-131 by talcum power and precipitated silica. Nature 212, 355-358

SAS (1987) SAS User's Guide: Statistics. Version 6 Edition, SAS Inst Inc, Cary, NC

Trinder $P$ (1969) Determination of glucose in blood using glucose oxidase with an alternative oxygen acceptor. Ann Clin Biochem 6, 24-27

Woods SC, Stein LJ, McKay LD, Porte D (1984) Suppresion of food intake by intravenous nutrients and insulin in the baboon. Am J Physiol 247, R393R401 